\title{
Treatment of Fresh Water Hyacinth with Essential Oil Emulsion and Subsequent Use of the Plant Material for Control of Aspergillus flavus on Rice Dessert Products
}

Sumethee Songsamoe and Narumol Matan *

\begin{abstract}
Essential oil emulsion, which is generally functionalized to have increased antifungal activity, has high solubility in water. The objective of this research was to develop an essential oil emulsion for absorption by water hyacinth plants in order to produce an essential oil absorbent material as a carrier of essential oil vapor that can be released to control mold in an enclosed packaging system. The fresh water hyacinth adsorbed the Michelia alba oil emulsion ( $100 \mu \mathrm{L} / \mathrm{mL}$ to $500 \mu \mathrm{L} / \mathrm{mL})$ through its root system, transporting it to the stems and leaves after submerging the plant into the $M$. alba oil emulsion for $48 \mathrm{~h}$. Dried sections (root, stem, and leaf) of the water hyacinth plant with absorbed $M$. alba essential oil emulsion released the $M$. alba vapor, inhibited Aspergillus flavus growth on malt extract agar (MEA), and also Thai dessert (Ja Mongkut) with the highest antifungal activity achieved with the concentration $500 \mu \mathrm{L} / \mathrm{mL}$. The maximum essential oil absorption $(345 \mu \mathrm{L} / \mathrm{g})$ in the fresh plant was achieved after $48 \mathrm{~h}$. The dried water hyacinth ( $\geq 0.4 \mathrm{~g} / \mathrm{L}$ air) completely inhibited the growth of $A$. flavus for at least 7 days. In addition, the absorbent material prevented the growth of $A$. flavus on the Thai dessert (Ja Mongkut) with approximately $100 \%$ effectiveness (versus the control) for 10 days, thereby extending the shelf-life 2.5 -fold in when compared with the control without essential oil.
\end{abstract}

Keywords: Absorbent material; Aspergillus flavus; Essential oil emulsion; Water hyacinth

Contact information: Food Science and Technology, School of Agricultural Technology, Walailak University, Nakhon Si Thammarat 80160, Thailand;

*Corresponding author: nnarumol@yahoo.com

\section{INTRODUCTION}

The growth of spoilage fungi and pathogenic molds on rice grains is undesirable, as it affects the quality of grain by causing discoloration, loss in dry matter, degradation of lipids and proteins, texture changes, and off odors (Christensen 1978). Moreover, some molds produce mycotoxins, namely aflatoxin, ochratoxin, and deoxynivalenol, which are associated with a high risk of human health problems if ingested (Magan and Aldred 2007; Reddy et al. 2011). There are many reports of contaminated mold or mycotoxin from rice grains affecting rice products (Iqbal et al. 2016), such as brown rice snack bars deteriorated by Aspergillus flavus and natural mold within $3 \mathrm{~d}$ of storage (Suhem et al. 2015). Many Thai desserts also have a short shelf-life caused by mold spoilage, which is a major issue for the Thai dessert business (Nopwinyuwong et al. 2010). Thus, finding alternative methods for controlling mold is necessary to improve the safety and quality of grains and grain products. 
Currently, many types of natural antimicrobial agents are applied in food products to avoid the use of chemical preservatives. Essential oil is one of the most interesting natural antimicrobial agents because it contains numerous natural compounds that can inhibit microbial growth (Chen et al. 2014; Tao et al. 2019). Application of essential oil in the vapor phase in antimicrobial packaging as a means to inhibiting mold on food has been demonstrated to be effective and harmless for humans (Tyagi et al. 2012; Suhem et al. 2019). However, the essential oil vapor can easily vaporize over time, so high concentrations are required for long term storage. Therefore, many researchers are trying to create food packaging with a vapor-based essential oil absorbent material, such as edible films, coatings, and sachets or pads (Oral et al. 2009; Seo et al. 2012; Balaguer et al. 2013).

The water hyacinth (Eichhornia crassipes (Mart.) Solms) is normally found in garden ponds around tropical and subtropical regions (Zhang et al. 2010). This plant is known to grow quickly, forming a large plant on the surface of the water (Villamagna and Murphy 2010) that rapidly covers the pond surface in a short time (Malik 2007). In fact, it can double in size between $6 \mathrm{~d}$ to $28 \mathrm{~d}$ and weigh in the range of 270 tons per hectare to 400 tons per hectare (Epstein 1998; Malik 2007). According to its extensive root system, the water hyacinth root can consume large amounts of chemical pollutants in the water (Gong et al. 2018), and its high cellulose polymer content can be used to produce low-cost cellulose membranes and cellulose nanofibers (Sundari and Ramesh 2012; Istirokhatun et al. 2015).

The objective of this research was to develop an essential oil emulsion for absorption by freshly harvested water hyacinth plants and thereafter to produce an absorbent material serving as a carrier of the essential oil. The concept is that the vapor of the essential oil can be released to control mold in an enclosed packaging system.

\section{EXPERIMENTAL}

\section{Materials}

Essential oil

Michelia alba oil, derived by steam distillation, was provided by the Thai China Flavors \& Fragrances Industry Co., Ltd. (Bangkok, Thailand). Linalool (73.74\%) and caryophyllene $(7.35 \%)$ are the two main compounds of Michelia oil.

\section{Water hyacinth plants}

The water hyacinth plant $(60 \pm 5 \mathrm{~g})$, including all the leaves and stem with a diameter of $25 \mathrm{~cm}, 30 \mathrm{~cm}$ in height, and roots 6 -cm-width $\times 0.2-\mathrm{cm}$-thick $\times 20$-cm-length, was harvested from a pond at Walailak University, Nakhon Si Thammarat, Thailand. Before use, the whole plant was washed eight times by dipping into deionized water for 48 h.

\section{Culture}

Aspergillus flavus $\left(10^{6} \mathrm{CFU} / \mathrm{mL}\right)$ was isolated from brown rice. The A. flavus was cultured on malt extract agar (MEA) before incubation at $25^{\circ} \mathrm{C}$ for 7 days. Spore suspensions of A. flavus $\left(10^{-1}-10^{-8}\right.$ spore $\left.\mathrm{ml}^{-1}\right)$ were collected by flooding the surface of the plates 
with $\sim 9 \mathrm{~mL}$ of sterile water. The number of viable spores was checked by the plate count method (AOAC 1992).

\section{Methods}

Investigation of water hyacinth for essential oil emulsion absorption

First, the essential oil emulsion was prepared at concentrations of $100 \mu \mathrm{L} / \mathrm{mL}$ to $500 \mu \mathrm{L} / \mathrm{mL}$ by mixing $M$. alba oil, polyethylene glycol sorbitan monooleate (Tween 80 ; 3\%, w/w; Tariko Co., Ltd., Bangkok, Thailand), and distilled water. The solution was mixed using a magnetic stirrer for $1 \mathrm{~min}$ and then homogenized (T25 Digital Ultra-Turrax; IKA, Staufen, Germany) at 24,000 rpm for $20 \mathrm{~min}$. The droplet size of the emulsions was observed by microscope (Carl Zeiss Jena Gmbh, Oberkochen, Germany) for $60 \mathrm{~h}$, and the stability of emulsion (d) was also assessed.

Second, to investigate the ability of the water hyacinth to absorb an essential oil emulsion, the fresh plant was first submerged in each concentration of the essential oil emulsion $(100 \mu \mathrm{L} / \mathrm{mL}$ to $500 \mu \mathrm{L} / \mathrm{mL})$ at room temperature. The flow of essential oil into the plant and capacity of the essential oil emulsion in each plant was assessed every $6 \mathrm{~h}$ for $60 \mathrm{~h}$. Then, the plant was dried at $50{ }^{\circ} \mathrm{C}$ in a hot air oven for $12 \mathrm{~h}$. Next, the dried plant was ground and kept at $20^{\circ} \mathrm{C}$ and $65 \%$ relative humidity before it was weighed using a digital balance (PA214; Ohaus Co., Ltd., Parsippany, NJ, USA) or 14\% moisture content was achieved. A control treatment was performed in the same way but without essential oil. The capacity of essential oil uptake in water hyacinth plant during and after the absorption process was calculated according to Eqs. 1 and 2, respectively,

Essential oil emulsion uptake capacity $(\mu \mathrm{L} / \mathrm{g})=V_{\mathrm{t}} / W$

where $V_{\mathrm{t}}$ is the absorbed volume of essential oil emulsion $(\mu \mathrm{L})$, at time and $W$ is the initial wet weight of water hyacinth plant $(\mathrm{g})$,

Pure essential oil uptake capacity $(\mu \mathrm{L} / \mathrm{g})=\left(V_{\mathrm{t}} \times C\right) / W$

where $V_{\mathrm{t}}$ is the absorbed volume of essential oil emulsion $(\mu \mathrm{L})$, at time $t, C$ is the concentration of essential oil emulsion $(\mu \mathrm{L} / \mathrm{mL})$, and $W$ is the initial wet weight of water hyacinth plant $(\mathrm{g})$.

The morphology of the water hyacinth plant before and after uptake of the essential oil emulsion was observed using an epifluorescent microscope and Nile red (SigmaAldrich, St. Louis, MO, USA) fluorescent lipophilic stain. The Nile red solution was prepared by dissolving it in methanol at a concentration of $1 \mathrm{~g} / \mathrm{L}$. The plant sections were stained by Nile red solution, placed on a glass slide, enclosed with a cover slip, and observed under an epifluorescent microscope (Nikon Eclipse E600 Microscope Y-FL EPI Fluorescence Attachment; Nikon, Tokyo, Japan) using excitation wavelengths from 380 $\mathrm{nm}$ to $420 \mathrm{~nm}$.

Antifungal effect of the absorbent material made from water plants containing essential oil against $A$. flavus

To develop an absorbent material from the water plant, each root, stem, and leaf of water plant was cut and dried in a tray for $12 \mathrm{~h}$ at $50^{\circ} \mathrm{C}$. Then, $0.2 \mathrm{~g}$ to $2.4 \mathrm{~g}$ of the dried plant parts were packed into a cellulose bag before they were placed into a 1-L plastic box. Mycelia of $A$. flavus (diameter approximately $5 \mathrm{~mm}$ ) grown for 7 days on MEA were added 
to the center of a MEA plate and added into the plastic box. In addition, a spore suspension of A. flavus $(0.1 \mathrm{~mL})$ was spread on a MEA plate and placed into the plastic box. All plates (without lid) inside the box were incubated at $25^{\circ} \mathrm{C}$ for 7 days. The colony diameter (mm) of $A$. flavus on each plate was checked every day for 7 days. The MIC was defined as the lowest concentration tested for which no mold growth was detected. Every test was performed in triplicate and palm oil (Morakot Industries PCL, Bangkok, Thailand) was used as a control.

Antifungal effect of the developed absorbent material on the growth of A. flavus on rice dessert products

Rice desserts (Ja Mongkuts) were produced using a Thai traditional recipe, rice flour (made from rice grain), sugar, egg yolk, coconut milk, and watermelon seeds as the main ingredients. After stirring all ingredients at $60{ }^{\circ} \mathrm{C}$ for $30 \mathrm{~min}$, the paste was added into the flour base before adding the melon seeds. Before testing, the desserts were exposed to UV-C radiation ( $\lambda=253.7 \mathrm{~nm}$, Phillips UV-C $30 \mathrm{~W}$ lamp; Phillips, Amsterdam, Netherlands) for $30 \mathrm{~min}$ in a biological safety cabinet (Cellgard, Charlotte, NC, USA). The desserts were then incubated with the A. flavus spore suspension at $25^{\circ} \mathrm{C}$ and $100 \%$ relative humidity for $10 \mathrm{~d}$ in the $1-\mathrm{L}$ plastic box with $1 \mathrm{~g}$ of dried water plant containing $M$. alba emulsion $(100 \mu \mathrm{L} / \mathrm{mL}$ to $500 \mu \mathrm{L} / \mathrm{mL}$ ). Palm oil (Morakot Industries PCL, Bangkok, Thailand) at the same concentrations was used as a control. The inhibitory period (d) was recorded as the time when no growth of mold on the surface was observed. The number of A. flavus was also counted on MEA plates. Then, the percent inhibition of mold growth was calculated by the following Eq. 3,

$$
\text { Inhibition }(\%)=\left(\left(N_{\mathrm{c}}-N_{\mathrm{s}}\right) / N_{\mathrm{c}}\right) \times 100
$$

where $N_{\mathrm{c}}$ is the colony count number $\left(\log _{10} \mathrm{cfu} / \mathrm{mL}\right)$ in the control and $N_{\mathrm{s}}$ is the number of the colony count $\left(\log _{10} \mathrm{cfu} / \mathrm{mL}\right)$ in the sample.

In addition, the dessert specimens with $1 \mathrm{~g}$ of dried water plant containing M. alba emulsion $(100 \mu \mathrm{L} / \mathrm{mL}$ to $500 \mu \mathrm{L} / \mathrm{mL})$ and the control stored at $25{ }^{\circ} \mathrm{C}$ for $48 \mathrm{~h}$ were subjected to sensory analysis by an untrained panel (43 panelists: 25 females and 18 males) that ranged from 18 to 45 years of age. Panelists were selected from students and staffs at Walailak University, Nakon Si Tammarat, Thailand. The dessert was randomly coded and presented to each panelist seated separately in a control booth. A 9-point hedonic scale ranging from "like extremely" to "dislike extremely" was used to determine the degree of acceptance of the specimens (Meilgaard et al. 1999).

\section{Fourier transform infrared spectroscopy (FTIR)}

Fourier transform infrared spectroscopy was used to investigate the changes in chemical bonds on the surface of the dried absorbent (without $M$. alba oil emulsion and $500 \mu \mathrm{L} / \mathrm{mL}$ ). The internal reflection crystal, which was made of zinc selenide, had a $45^{\circ}$ angle of incidence to the IR beam. Spectra were acquired at a resolution of $4 \mathrm{~cm}^{-1}$ and the measurement range was from $4000 \mathrm{~cm}^{-1}$ to $600 \mathrm{~cm}^{-1}$ (mid-IR region) at room temperature. Automatic signals were collected in 32 scans at a resolution of $4 \mathrm{~cm}^{-1}$ and normalized against a background spectrum recorded from the clean, empty cell at $25{ }^{\circ} \mathrm{C}$. Analysis of spectral data was completed using the Spectrum One software program (Perkin Elmer, 
version 6.3.5, Waltham, MA, USA). A change in the chemical composition of each sample was observed (Suhem et al. 2017).

\section{Statistical analysis}

All results were expressed as the mean \pm standard deviation. One-way analysis of variance (ANOVA) and Duncan's post hoc test, with $\mathrm{p}<0.05$ being considered statistically significant, were employed in the statistical analysis using Statistica software (StatSoft Inc., version 11.0, Tulsa, OK, USA).

\section{RESULTS AND DISCUSSION}

\section{Living Water Hyacinth Plant Adsorption Behavior}

The different concentrations of $M$. alba oil emulsion and oil droplets were observed to be dispersed in the emulsion after homogenization. The smallest essential oil droplets were found homogeneously dispersed in the continuous phase (oil in water). After storage for $60 \mathrm{~h}$, the droplet size of essential oil slightly increased, and the emulsion was stable for at least $3 \mathrm{~d}$ before it began to separate (Table 1). Essential oil emulsion uptake capacity and pure essential oil uptake capacity of water hyacinth plant are shown in Figs. 1 and 2. The results indicated that the water hyacinth plant absorbed the $M$. alba oil emulsion at high concentrations $(400 \mu \mathrm{L} / \mathrm{mL}$ to $500 \mu \mathrm{L} / \mathrm{mL})$ better than at low concentrations $(100 \mu \mathrm{L} / \mathrm{mL}$ to $300 \mu \mathrm{L} / \mathrm{mL})(\mathrm{p}<0.05)$, and the uptake gradually decreased and stopped within 48 hour.

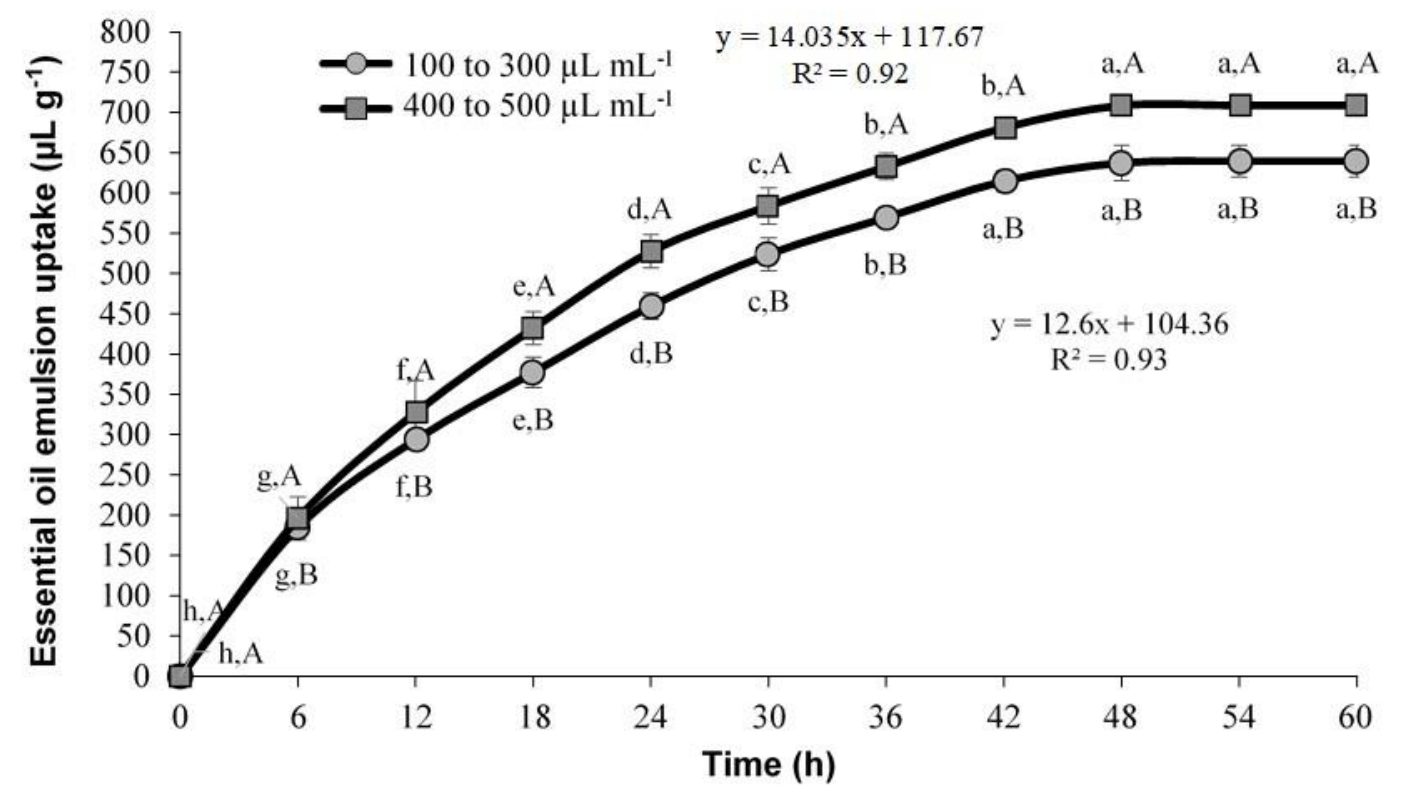

Fig. 1. Essential oil emulsion uptake capacity of the water hyacinth plant for $60 \mathrm{~h}$ : a-h: Letters in lowercase that appear horizontally for each concentration are significantly different $(p<0.05)$; A$B$ : Letters in uppercases that appear vertically for each concentration are significantly different $(p$ $<0.05)$ 


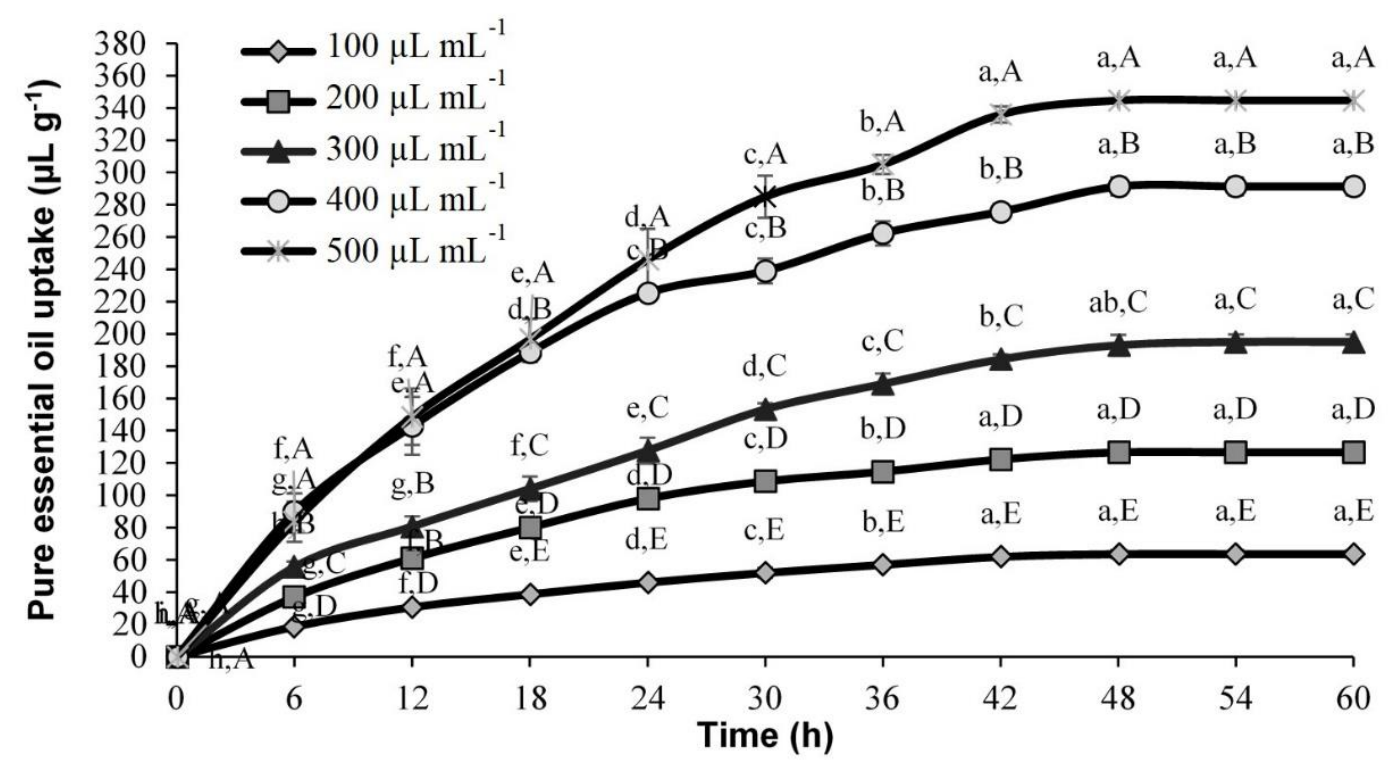

Fig. 2. Pure essential oil uptake capacity of water hyacinth plant for $60 \mathrm{~h}$ : a-h: Letters in lowercase that appear horizontally for each concentration are significantly different $(p<0.05)$; A-D: Letters in uppercases that appear vertically for each concentration are significantly different $(p<0.05)$

Table 1. Stability of M. alba Oil Emulsion

\begin{tabular}{|c|c|c|c|}
\hline Concentration $(\mu \mathrm{L} / \mathrm{mL})$ & Stability Time $(\mathrm{d})$ & \multicolumn{2}{|c|}{ Oil Droplet Mean Diameter $(\mu \mathrm{m})$} \\
\hline & & $\begin{array}{c}\text { After } \\
\text { Homogenization }\end{array}$ & After $60 \mathrm{~h}$ \\
\hline 100 & 4 & 1.23 & 1.49 \\
\hline 200 & 4 & 1.57 & 1.86 \\
\hline 300 & 4 & 1.61 & 2.08 \\
\hline 400 & 3 & 1.71 & 2.40 \\
\hline 500 & 3 & 2.09 & 2.73 \\
\hline
\end{tabular}

The fluorescence ( $380 \mathrm{~nm}$ to $420 \mathrm{~nm}$ wavelengths) micrographs of essential oil in the plant are shown in Fig. 3. The M. alba emulsion was observed in the lipophilic parts of the plant tissue, as indicated by the fluorescence in the root, stem, and leaves, with the highest concentration found in the root.

The results from this study confirmed that water hyacinth could also absorb essential oil emulsions. The essential oil emulsion passed through the vascular tissue system of the aquatic vascular plants before accumulation in the root, stem, and leaf sections. The water hyacinth reached its capacity of essential oil emulsion within $48 \mathrm{~h}$. In comparison with other substances, the whole plant of water hyacinth after submersion or floating on hazardous wastewater was found to be fresh (Mukherjee and Mondal 1995; Al Rmalli et al. 2005; Malik 2007) and difficult to harvest. 

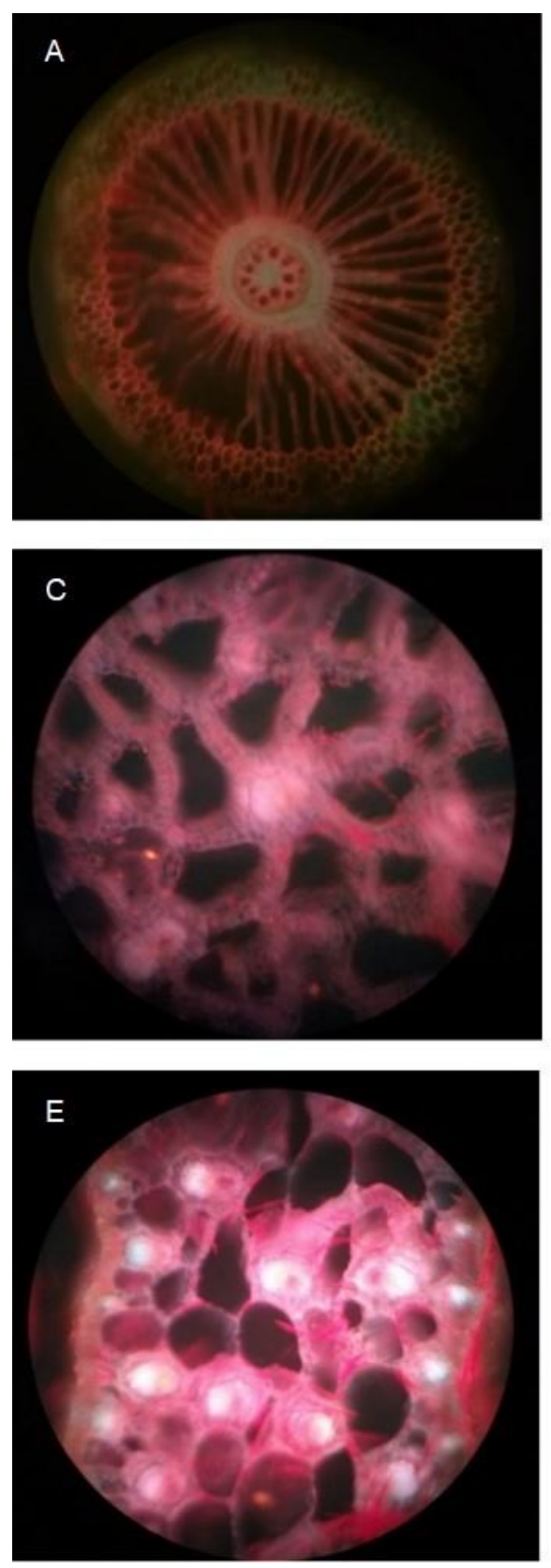
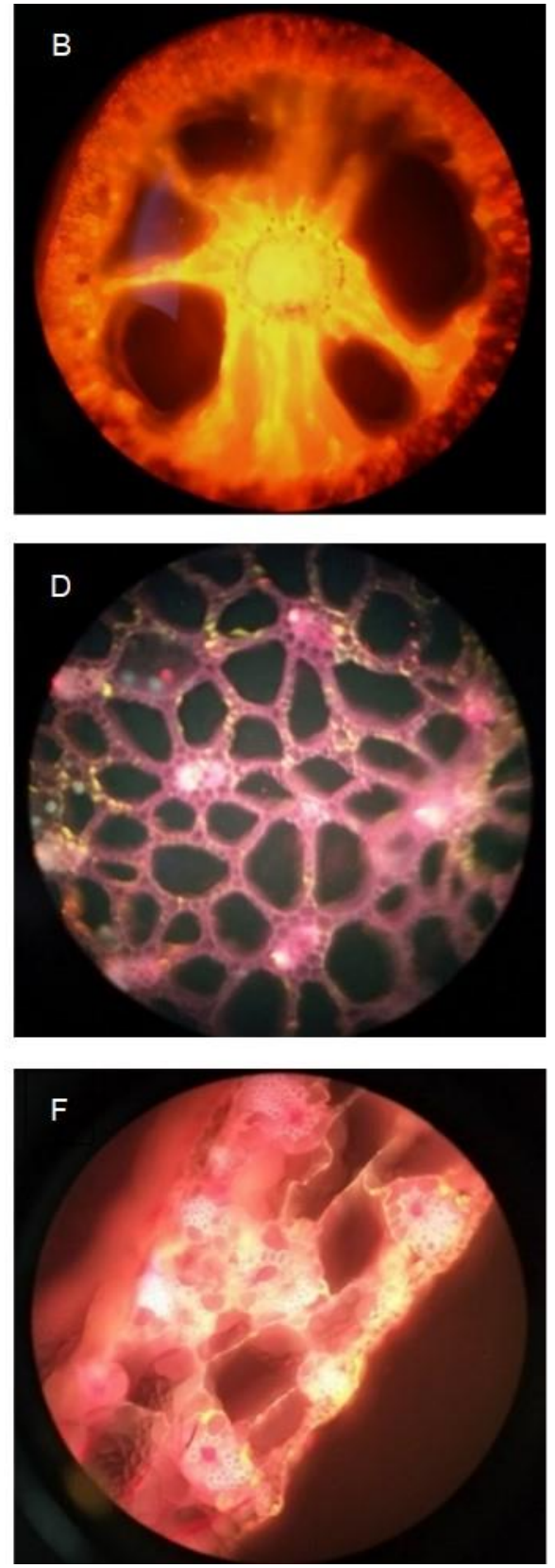

Fig. 3. Fluorescence micrographs of cross-section of the root ( $A$ and $B)$, stem ( $C$ and $D$ ), and leaf ( $E$ and $F$ ) of the water hyacinth plant before dipping $(A, C, E)$, and after dipping $(B, D, F)$ into the essential oil emulsion. Essential oil bodies were stained using Nile Red and appeared yellow under the fluorescence.

Water hyacinth plants are known to have an extensive root system, a large number of cells, and high absorption capacity, and thereby possess ability to absorb a large volume of water, chemical, heavy metal, and waste liquid into its cells via the vascular tissue system (Mishra and Tripathi 2009). Consequently, water hyacinth has been used for many absorption purposes, such as reducing chemical substances and removal of toxins or hazardous chemicals from wastewater (Low et al. 1995; Carvalho Dos Santos and Lenzi 2000; 
Hasan et al. 2010; Murithi et al. 2014; Gong et al. 2018). For example, Mukherjee and Mondal (1995) showed that the living water hyacinth reduced the concentration of $\mathrm{Pb}(0.5$ $\mathrm{mg} / \mathrm{L}$ to $10 \mathrm{mg} / \mathrm{L}$ ) by $85 \%$ to $92 \%$ within 10 days. Delgado et al. (1993) reported that living water hyacinth completely removed $\mathrm{Zn}, \mathrm{Cr}$, and $\mathrm{Cd}$ from water within 24 hour. Furthermore, Al Rmalli et al. (2005) showed that the powdered dried root of water hyacinth absorbed $93 \%$ of As (III) and 95\% of As (V) from $200 \mu \mathrm{g} \mathrm{As} / \mathrm{L}$ within $60 \mathrm{~min}$. Additionally, Low et al. (1995) revealed that the dried roots of water hyacinth have a similarly high ability to absorb and remove two basic dyes (methylene blue and Victoria blue) from aqueous solutions as commercial activated carbon.

The morphology of the water hyacinth plant after uptake of the essential oil emulsion (Fig. 3) and the antifungal activity of the absorbent from each section of plant (Fig. 4) demonstrated that water hyacinth plant absorbed essential oil emulsion and accumulated it in the root section with the highest level of essential oil, followed by stem and leaf sections. This phenomenon has also previously been observed and reported (Mishra and Tripathi 2009).

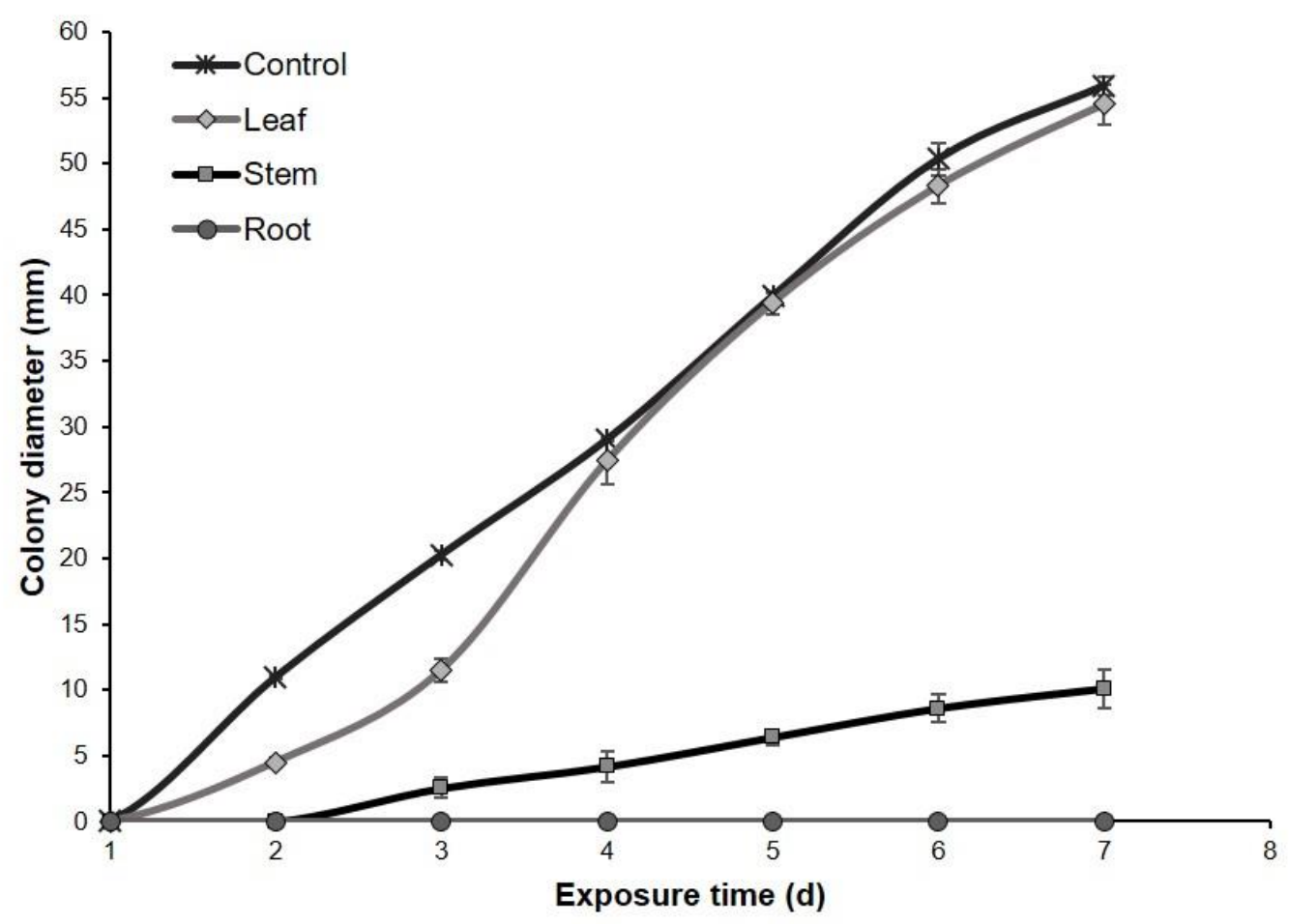

Fig. 4. Effects of $M$. alba vapor released from each section of the dried water hyacinth $(0.4 \mathrm{~g} / \mathrm{L})$ air aborbed $M$. alba oil emulsion at concentration of $500 \mu \mathrm{L} / \mathrm{mL}$ on the mycelium growth of $A$. flavus

This research also confirmed that essential oil in the form of an emulsion could be taken up by the water plants. The essential oil in an emulsion was stable, and the constant small droplet size helped disperse the essential oil in the plant after absorption, and was less costly for large-scale essential oil preparation (Donsì and Ferrari 2016). Moreover, the small droplets enhanced the transportation of active molecules throughout the cell membranes, thereby achieving higher antifungal activity. Furthermore, the water hyacinth absorbed the essential oil emulsion by its natural vascular system without the need for any 
additional devices, such as a high-pressure pump, and therefore the absorption process does not require additional energy costs.

The essential oil (M. alba) emulsion was created to improve the dispersion of oil in the water phase for absorption by the plant. The results of this experiment confirmed that the polysorbate 80 (Tween $80 ; 3 \%, \mathrm{w} / \mathrm{w}$ ) and colloid milling homogenization could be used to prepare a high-quality essential oil emulsion with small-sized droplets, good oil dispersion, and satisfactory stability. These results agreed with many reports that high shear homogenization could be used to create essential oil emulsions at a low cost (Donsì et al. 2012; Ribes et al. 2016). Polysorbate 80 is a non-ionic surfactant made from sorbitol, oleic acid, and epoxy ethane, which is widely used as an emulsifier, solubilizer, and stabilizer in food, cosmetics, drugs, and biodegradation media due to its high surface activity and low toxicity (Pan et al. 2016). Hence, it is considered safe for the production of essential oil emulsion.

\section{MICs of Plant Absorbent Material Containing M. alba Oil}

The effects of $M$. alba vapor released from sections of the root, stem, and leaf (of the dried water hyacinth plants) absorbent material on the mycelium growth of A. flavus in MEA are presented in Fig. 4 and Table 2. The results showed that the absorbents from all parts of the plant reduced the growth of A. flavus for 7 days at $25{ }^{\circ} \mathrm{C}$. The root section of the dried plant had the highest antifungal activity, followed by stem and leaf section, respectively (Fig. 4). The highest concentration of $500 \mu \mathrm{L} / \mathrm{mL}$ was more effective at preventing A. flavus growth than the lowest concentration of $100 \mu \mathrm{L} / \mathrm{mL}$. However, it was observed that the $M$. alba oil emulsion at $200 \mu \mathrm{L} / \mathrm{mL}$ had similar antifungal activity with the $500 \mu \mathrm{L} / \mathrm{mL}$ concentration

Additionally, the MIC values of the dried water hyacinth plants on the spore germination of A. flavus are presented in Table 2. The results indicated that the root section of the dried plant had the highest antifungal activity, and $\geq 0.4 \mathrm{~g} / \mathrm{L}$ air completely inhibited the growth of A. flavus for at least 7 days.

While the stem of the dried plant had lower antifungal activity than the root section, the MIC of all treatments was not less than $0.8 \mathrm{~g} / \mathrm{L}$ air. The leaf section of the dried plant showed the lowest antifungal activity, and the MIC of all treatments was not less than 2.0 g/L air.

The antifungal activity depended on the volume of pure essential oil in plant, and antifungal activity increased when the volume of pure essential oil in the plant increased. Additionally, the micrographs confirmed that the highest volume of essential oil was detected in the root section, followed by the stem and leaf. 
Table 2. MICs of Plant Absorbent Material Containing M. alba Oil on the Growth of $A$. flavus

\begin{tabular}{|c|c|c|}
\hline Treatments & Part of Dried Plant & MIC $(\mathrm{g} / \mathrm{L}$ air $)$ \\
\hline \multirow{3}{*}{ Dried plant absorbed EO $100 \mu \mathrm{L} / \mathrm{mL}$} & Root & 1.6 \\
\cline { 2 - 3 } & Stem & 2.0 \\
\cline { 2 - 3 } & Leaf & $>2.4$ \\
\hline \multirow{3}{*}{ Dried plant absorbed EO $200 \mu \mathrm{L} / \mathrm{mL}$} & Root & 0.8 \\
\cline { 2 - 3 } & Stem & 1.0 \\
\cline { 2 - 3 } & Leaf & 2.0 \\
\hline \multirow{2}{*}{ Dried plant absorbed EO $300 \mu \mathrm{L} / \mathrm{mL}$} & Root & 1.0 \\
\cline { 2 - 3 } & Stem & 1.2 \\
\cline { 2 - 3 } & Leaf & 2.4 \\
\hline \multirow{3}{*}{ Dried plant absorbed EO $400 \mu \mathrm{L} / \mathrm{mL}$} & Root & 1.0 \\
\cline { 2 - 3 } & Stem & 1.2 \\
\cline { 2 - 3 } & Leaf & 2.0 \\
\hline \multirow{2}{*}{ Dried plant absorbed EO $500 \mu \mathrm{L} / \mathrm{mL}$} & Root & 0.4 \\
\cline { 2 - 3 } & Stem & 0.8 \\
\cline { 2 - 3 } & Leaf & 2.0 \\
\hline
\end{tabular}

\section{Shelf-life Extension of Thai Dessert}

Mold inhibition (\%) and period inhibition (day) of A. flavus on rice dessert (Ja Mongkut) are presented in Table 3. The results indicated that the dried plant absorption material that contained the emulsion of $M$. alba oil $(500 \mu \mathrm{L} / \mathrm{mL})$ prevented the growth of A. flavus on Ja Mongkut with approximately $100 \%$ effectiveness (based control) for 10 days, thereby extending the shelf-life of the Ja Mongkut 2.5-fold when compared with the control without essential oil (4 days). Furthermore, at highest concentration $(500 \mu \mathrm{L} / \mathrm{mL})$, the sensory test results showed that the consumer gave higher scores (9 point hedonic of "like slightly" to "like moderately") to Ja Mongkut with $M$. alba vapor than the control (neither like nor dislike).

Table 3. Inhibition and Inhibition Period of $A$. flavus on Thai Dessert after Being Packed with $1 \mathrm{~g}$ of Absorbent Material Containing M. alba oil

\begin{tabular}{|c|c|c|}
\hline Samples & Inhibition (\%) & Period Inhibition (d) \\
\hline Absorbed EO $100 \mu \mathrm{L} / \mathrm{mL}$ & 10 & 4 \\
\hline Absorbed EO $200 \mu \mathrm{L} / \mathrm{mL}$ & 93 & 8 \\
\hline Absorbed EO $300 \mu \mathrm{L} / \mathrm{mL}$ & 70 & 6 \\
\hline Absorbed EO $400 \mu \mathrm{L} / \mathrm{mL}$ & 87 & 7 \\
\hline Absorbed EO $500 \mu \mathrm{L} / \mathrm{mL}$ & 100 & 4 \\
\hline Control & 0 & 10 \\
\hline
\end{tabular}

\section{Possible Modes of Action}

The FTIR spectra of the dried water hyacinth with and without $M$. alba oil emulsion and linalool emulsion are shown in Fig. 5. The FTIR spectra of all sections of water hyacinth (root, stem, and leaf) containing $M$. alba oil emulsion displayed some characteristic changes (compared with control), especially in the peak range of $3000 \mathrm{~cm}^{-1}$ to $2800 \mathrm{~cm}^{-1}$ (representative of $\mathrm{C}-\mathrm{H}$ groups). 


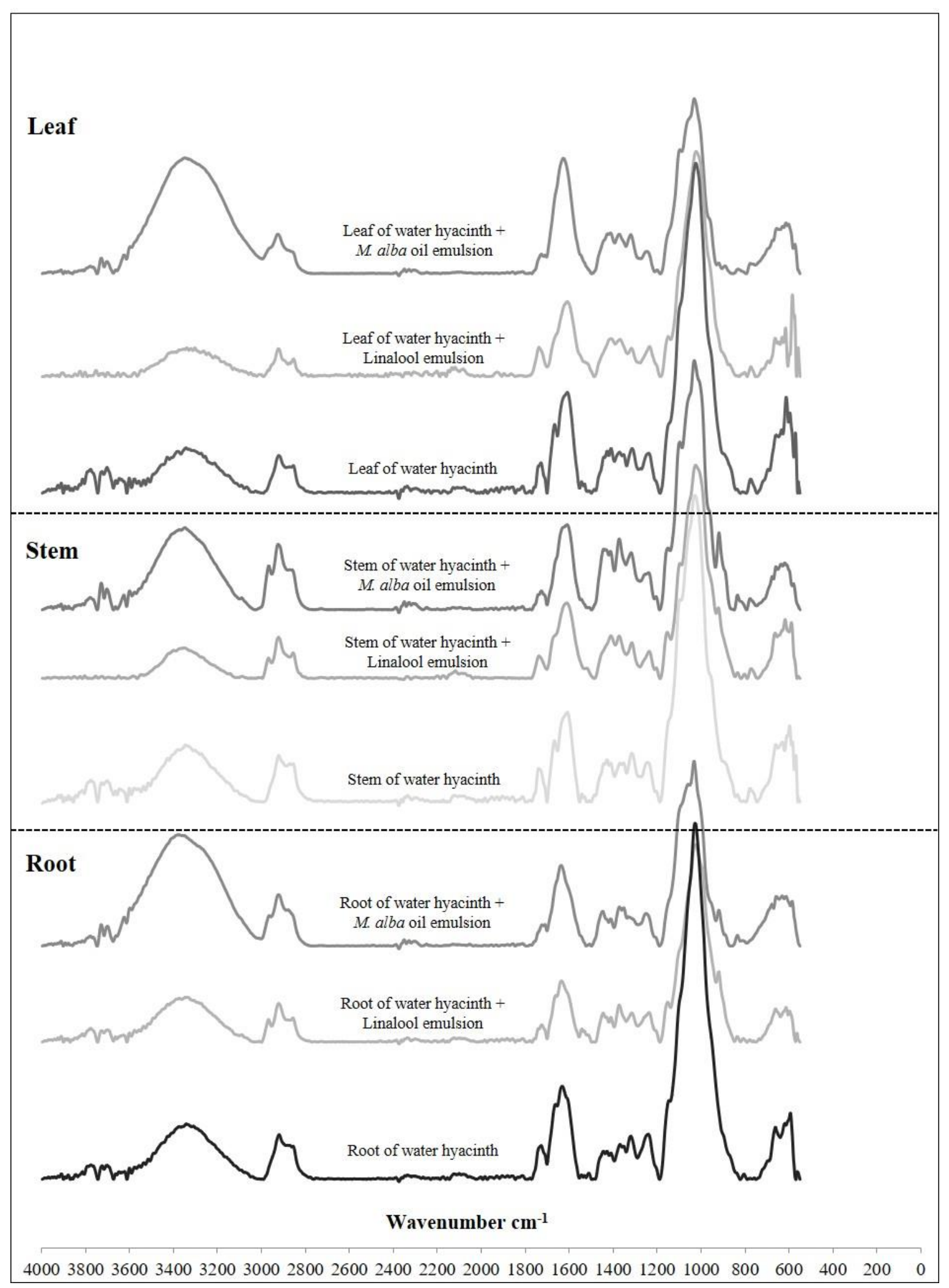

Fig. 5. FTIR spectra of absorbent from water hyacinth (root, stem, and leaf) with and without $M$. alba oil emulsion and linalool emulsion 
In addition, the amplitude of the peak range of 900 to $1200 \mathrm{~cm}^{-1}$ (representative of $\mathrm{C}-\mathrm{O}-\mathrm{C}$ and C-O stretching the ester bond), 1200 to $1700 \mathrm{~cm}^{-1}$ (representative of C-OH, C$\mathrm{C}$ and $\mathrm{C}-\mathrm{O}-\mathrm{C}$ stretching), and 1625 to $1710 \mathrm{~cm}^{-1}$ (representative of $\mathrm{C}=\mathrm{O}$ stretching and hydrogen bonding coupled with $\mathrm{COO}^{-1}$, respectively) decreased, whereas the region of 3000 to 3700 (representative of hydrogen stretching the $\mathrm{H}$-bonded $\mathrm{OH}$ group) clearly increased. Additionally, the peak pattern of water hyacinth containing $M$. alba oil emulsion was similar to that of the water hyacinth containing the linalool emulsion. In the comparison of the FTIR results of each section of the dried plant, the peak pattern of root and stem sections clearly changed, whereas the peak pattern of the leaf section showed little change when compared with the control.

The FTIR spectra of all sections of water hyacinth (root, stem, and leaf) containing M. alba oil emulsion suggested that linalool was the main active component of the essential oil emulsion, as peak pattern changes in the peak range of $3000 \mathrm{~cm}^{-1}$ to $2800 \mathrm{~cm}^{-1}$ might have indicated changes in the $\mathrm{C}-\mathrm{H}$ group of linalool. Previous studies by Kinninmonth et al. (2013) and Rani et al. (2014) reported that the peak at $2923 \mathrm{~cm}^{-1}$ to $3000 \mathrm{~cm}^{-1}$ indicates the presence of $\mathrm{C}-\mathrm{H}$ stretching in linalool. In addition, changes of the amplitude of the other peak ranges suggested that $M$. alba oil emulsion could be incorporated into the water hyacinth and active on the surface, and this binding might cause a change in the water hyacinth structure, which may affect its physical properties.

This study was aimed at developing an essential oil absorbent material from water hyacinth plant for use as an antifungal agent in rice desserts. The findings from this study confirmed that the developed absorbent from the water hyacinth plant could be applied to prevent mold growth on the surface of rice dessert. The $M$. alba oil contains aroma constituents and bioactive components that have been used as anti-inflammatory agents to treat cramps, abdominal pain (Lee et al. 2005), fever, syphilis, and malaria (Asaruddin et al. 2003). Additionally, it has been shown to inhibit the growth of Aspergillus niger, Aspergillus flavus, Penicillium sp., Rhizopus sp., Fusarium sp., and Cladosporium sp. (Songsamoe et al. 2017; Suhem et al. 2017). Moreover, its major component, linalool, has been shown to inhibit bacteria and molds, such as Escherichia coli, Staphylococcus aureus, Bacillus subtilis, Pseudomonas aeruginosa, Botrytis cinerea, Candida albicans, Penicillium italicum, and Fusarium oxysporum (Bakkali et al. 2008; Shimada et al. 2014). The findings from this study confirmed that the developed absorbent from the water hyacinth plant could be applied to prevent mold growth on the surface of rice dessert. The vapor phase of the active main component of $M$. alba oil, linalool, was released from the plant absorbent material ( $\geq 0.4 \mathrm{~g} / \mathrm{L}$ air) and inhibited mold growth on the rice-based dessert while maintaining the flavor of the dessert.

\section{CONCLUSIONS}

1. The $M$. alba oil emulsion at concentrations from $100 \mu \mathrm{L} / \mathrm{mL}$ to $500 \mu \mathrm{L} / \mathrm{mL}$ was absorbed into the plant via the plant vascular system.

2. The $M$. alba oil emulsion at a concentration of $500 \mu \mathrm{L} / \mathrm{mL}$ in the root exhibited the highest inhibition for mold growth 
3. The vapor of $M$. alba oil released from the absorbent $(500 \mu \mathrm{L} / \mathrm{mL})$ from the root $(1 \mathrm{~g})$ inhibited fungal growth, which extended the shelf-life of the Ja Mongkut up to 10 days, with a high score of 9 points on the hedonic scale.

4. The novel absorbent material from water hyacinth plants containing essential oil emulsion has great potential as a food preservative in packaging for rice desserts to prevent against fungal spoilage.

\section{ACKNOWLEDGMENTS}

This study was supported by the Thailand Research Fund (TRF) through the Royal Golden Jubilee Ph.D. Program (Grant No. PHD/0090/2014), the Walailak University Fund.

\section{REFERENCES CITED}

Al Rmalli, S. W., Harrington, C. F., Ayub, M., and Haris, P. I. (2005). “A biomaterial based approach for arsenic removal from water," J. Environ. Monitor. 7(4), 279-282. DOI: 10.1039/B500932D

AOAC International. (1992). FDA Bacteriology Analytical Manual, $7^{\text {th }}$ Edition, Arlington, VA 22201-3301 USA, 227-234.

Asaruddin, M. R., Honda, G., Tsubouchi, A., Nakajima-Shimada, J., Aoki, T., and Kiuchi, F. (2003). "Trypanocidal constituents from Michelia alba," Nat. Med. 57(2), 61-63.

Bakkali, F., Averbeck, S., Averbeck, D., and Idaomar, M. (2008). "Biological effects of essential oils - A review," Food Chem. Toxicol. 46(2), 446-475. DOI: 10.1016/j.fct.2007.09.106

Balaguer, M. P., Lopez-Carballo, G., Catala, R., Gavara, R., and Hernandez-Munoz, P. (2013). "Antifungal properties of gliadin films incorporating cinnamaldehyde and application in active food packaging of bread and cheese spread foodstuffs," Int. J. Food Microbiol. 166(3), 369-377. DOI: 10.1016/j.ijfoodmicro.2013.08.012

Carvalho Dos Santos, M., and Lenzi, E. (2000). "The use of aquatic macrophytes (Eichhornia crassipes) as a biological filter in the treatment of lead contaminated effluents," Environ. Technol. 21(6), 615-622. DOI: 10.1080/09593330.2000.9618946

Chen, C., Tong, Z., Liao, D., Li, Y., Yang, G., and Li, M. (2014). "Chemical composition and antimicrobial and DPPH scavenging activity of essential oil of Toona sinensis (A. Juss.) Roem from China," BioResources 9(3), 5262-5278. DOI: 10.15376/biores.9.3.5262-5278

Christensen, C. M. (1978). "Fungi and seed quality," Outlook Agr. 9(5), 209-213. DOI: $10.1177 / 003072707800900503$

Delgado, M., Bigeriego, M., and Guardiola, E. (1993). "Uptake of Zn, Cr and Cd by water hyacinths," Water Res. 27(2), 269-272. DOI: 10.1016/0043-1354(93)90085-V

Donsì, F., and Ferrari, G. (2016). "Essential oil nanoemulsions as antimicrobial agents in food,” J. Biotechnol. 233, 106-120. DOI: 10.1016/j.jbiotec.2016.07.005 
Donsì, F., Annunziata, M., Vincensi, M., and Ferrari, G. (2012). "Design of nanoemulsion-based delivery systems of natural antimicrobials: Effect of the emulsifier," J. Biotechnol. 159(4), 342-350. DOI: 10.1016/j.jbiotec.2011.07.001

Epstein, P. (1998). "Weeds bring disease to the east African waterways," Lancet 351(9102), 577. DOI: 10.1016/s0140-6736(05)78570-6

Gong, Y., Zhou, X., Ma, X., and Chen, J. (2018). "Sustainable removal of formaldehyde using controllable water hyacinth". J. Clean. Prod. 181, 1-7. DOI: 10.1016/j.jclepro.2018.01.220

Hasan, S. H., Ranjan, D., and Talat, M. (2010). "Water hyacinth biomass (WHB) for the biosorption of hexavalent chromium: Optimization of process parameters," BioResources 5(2), 563-575. DOI: 10.15376/biores.5.2.563-575

Iqbal, S. Z., Asi, M. R., Hanif, U., Zuber, M., and Jinap, S. (2016). “The presence of aflatoxins and ochratoxin $\mathrm{A}$ in rice and rice products; and evaluation of dietary intake," Food Chem. 210, 135-140. DOI: 10.1016/j.foodchem.2016.04.104

Istirokhatun, T., Rokhati, N., Rachmawaty, R., Meriyani, M., Priyanto, S., and Susanto, H. (2015). "Cellulose isolation from tropical water hyacinth for membrane preparation," Procedia Environ. Sci. 23, 274-281. DOI:

10.1016/j.proenv.2015.01.041

Kinninmonth, M. A., Liauw, C. M., Verran, J., Taylor, R., Edwards-Jones, V., Shaw, D., and Webb, M. (2013). "Investigation into the suitability of layered silicates as adsorption media for essential oils using FTIR and GC-MS," Appl. Clay Sci. 83-84, 415-425. DOI: 10.1016/j.clay.2013.07.009

Lee, J., Jung, E., Park, J., Jung, K., Lee, S., Hong, S., Park, J., Park, E., Kim, J., Park, S., et al. (2005). "Anti-inflammatory effects of magnolol and honokiol are mediated through inhibition of the downstream pathway of MEKK-1 in NF- $\kappa$ B activation signaling," Planta. Med. 71(4), 338-343. DOI: 10.1055/s-2005-864100

Low, K. S., Lee, C. K., and Tan, K. K. (1995). "Biosorption of basic dyes by water hyacinth roots," Bioresource Technol. 52(1), 79-83. DOI: 10.1016/09608524(95)00007-2

Magan, N., and Aldred, D. (2007). "Post-harvest control strategies: Minimizing mycotoxins in the food chain," Int. J. Food Microbiol. 119(1-2), 131-139. DOI: 10.1016/j.ijfoodmicro.2007.07.034

Malik, A. (2007). "Environmental challenge vis a vis opportunity: The case of water hyacinth,” Environ. Int. 33(1), 122-138. DOI: 10.1016/j.envint.2006.08.004

Mishra, V. K., and Tripathi, B. D. (2009). "Accumulation of chromium and zinc from aqueous solutions using water hyacinth (Eichhornia crassipes)," J. Hazard. Mater. 164(2-3), 1059-1063. DOI: 10.1016/j.jhazmat.2008.09.020

Mukherjee, S., and Mondal, G. C. (1995). "Removal of lead by water hyacinth," Indian J. Chem. Technol. 2, 59-62.

Murithi, G., Onindo, C. O., Wambu, E. W., and Muthakia, G. K. (2014). "Removal of cadmium (II) ions from water by adsorption using water hyacinth (Eichhornia crassipes) biomass," BioResources 9(2), 3613-3631. DOI: 10.15376/biores.9.2.36133631

Nopwinyuwong, A., Trevanich, S., and Suppakul, P. (2010). "Development of a novel colorimetric indicator label for monitoring freshness of intermediate-moisture dessert spoilage," Talanta. 81(3), 1126-1132. DOI: 10.1016/j.talanta.2010.02.008. 
Oral, N., Vatansever, L., Sezer, Ç., Aydın, B., Güven, A., Gülmez, M., Baser, K. H. C., and Kürkçüoğlu, M. (2009). "Effect of absorbent pads containing oregano essential oil on the shelf life extension of overwrap packed chicken drumsticks stored at four degrees Celsius," Poultry Sci. 88(7), 1459-1465. DOI: 10.3382/ps.2008-00375

Pan, J., Ji, Y., Du, Z., and Zhang, J. (2016). "Rapid characterization of commercial polysorbate 80 by ultra-high performance supercritical fluid chromatography combined with quadrupole time-of-flight mass spectrometry," J. Chromatogr. A 1465, 190-196. DOI: 10.1016/j.chroma.2016.08.051

Rani, P. U., Madhusudhanamurthy, J., and Sreedhar, B. (2014). "Dynamic adsorption of $\alpha$-pinene and linalool on silica nanoparticles for enhanced antifeedant activity against agricultural pests," J. Pest Sci. 87(1), 191-200. DOI: 10.1007/s10340-013-0538-2

Reddy, K. R. N., Raghavender, C. R., Salleh, B., Reddy, C. S., and Reddy, B. N. (2011). "Potential of aflatoxin $\mathrm{B}_{1}$ production by Aspergillus flavus strains on commercially important food grains," Int. J. Food Sci. Technol. 46(1), 161-165. DOI: 10.1111/j.1365-2621.2010.02468.x

Ribes, S., Fuentes, A., Talens, P., and Barat, J. M. (2016). "Use of oil-in-water emulsions to control fungal deterioration of strawberry jams," Food Chem. 211, 92-99. DOI: 10.1016/j.foodchem.2016.05.040

Seo, H.-S., Bang, J., Kim, H., Beuchat, L. R., Cho, S. Y., and Ryu, J.-H. (2012). "Development of an antimicrobial sachet containing encapsulated allyl isothiocyanate to inactivate Escherichia coli O157: $\mathrm{H} 7$ on spinach leaves," Int. J. Food Microbiol. 159(2), 136-143. DOI: 10.1016/j.ijfoodmicro.2012.08.009

Shimada, T., Endo, T., Fujii, H., Rodríguez, A., Peña, L., and Omura, M. (2014). "Characterization of three linalool synthase genes from Citrus unshiu Marc. and analysis of linalool-mediated resistance against Xanthomonas citri subsp. citri and Penicillium italicum in citrus leaves and fruits," Plant Sci. 229, 154-166. DOI: 10.1016/j.plantsci.2014.09.008

Songsamoe, S., Matan, N., and Matan, N. (2017). "Antifungal activity of Michelia alba oil in the vapor phase and the synergistic effect of major essential oil components against Aspergillus flavus on brown rice," Food Control 77, 150-157. DOI: 10.1016/j.foodcont.2017.02.010

Suhem, K., Matan, N., and Matan, N. (2019). "Effect of high temperature with Litsea cubeba Pers. to control mold growth on bamboo food packaging and its possible modes of action," BioResources 14(1), 1289-1302. DOI: 10.15376/biores.14.1.12891302

Suhem, K., Matan, N., Matan, N., Danworaphong, S., and Aewsiri T. (2015). "Improvement of the antifungal activity of Litsea cubeba vapor by using a heliumneon (He-Ne) laser against Aspergillus flavus on brown rice snack bars," Int. J. Food Microbiol. 215, 157-160. DOI: 10.1016/j.ijfoodmicro.2015.09.008

Suhem, K., Matan, N., Matan, N., Danworaphong, S., and Aewsiri, T. (2017). "Enhanced antifungal activity of michelia oil on the surface of bamboo paper packaging boxes using helium-neon (HeNe) laser and its application to brown rice snack bar," Food Control 73, 939-945. DOI: 10.1016/j.foodcont.2016.10.006

Sundari, M. T., and Ramesh, A. (2012). "Isolation and characterization of cellulose nanofibers from the aquatic weed water hyacinth - Eichhornia crassipes," Carbohyd. Polym. 87(2), 1701-1705. DOI: 10.1016/j.carbpol.2011.09.076 
Tao, C., Wang, Y., Zhang, X., Li, L., Wu, Y., Han, X., Jiang, X., and Lv, Z. (2019). "Mechanism of action of essential oils extracted from bamboo (Phyllostachys heterocycla $\mathrm{cv}$. pubescens) leaves: Chemical composition and antimicrobial activity against four food-related microorganisms," BioResources 14(1), 1419-1434. DOI: 10.15376/biores.14.1.1419-1434

Tyagi, A. K., Malik, A., Gottardi, D., and Guerzoni, M. E. (2012). "Essential oil vapour and negative air ions: A novel tool for food preservation," Trends Food Sci. Tech. 26(2), 99-113. DOI: 10.1016/j.tifs.2012.02.004

Villamagna, A. M., and Murphy, B. R. (2010). "Ecological and socio-economic impacts of invasive water hyacinth (Eichhornia crassipes): A review," Freshwater Biol. 55(2), 282-298. DOI: 10.1111/j.1365-2427.2009.02294.x

Zhang, Y.-Y., Zhang, D.-Y., and Barrett, S. H. (2010). "Genetic uniformity characterizes the invasive spread of water hyacinth (Eichhornia crassipes), a clonal aquatic plant," Mol. Ecol. 19(9), 1774-1786. DOI: 10.1111/j.1365-294X.2010.04609.x

Article submitted: August 29, 2019; Peer review completed: November 23, 2019; Revised version received: January 6, 2020; Accepted: January 7, 2020; Published: February 3, 2020.

DOI: 10.15376/biores.15.2.2147-2162 